\title{
KAJIAN POTENSI EKSTRAK BUAH MENGKUDU (Morinda citrifolia) SEBAGAI DESINFEKTAN ALAMI TERHADAP JAMUR PADA RUANG PENYIMPANAN SUSU
}

\section{STUDY OF THE POTENTIAL OF (Morinda citrifolia) EXTRACT AS A NATURAL DESINFECTANT OF FUNGUS IN MILK STORAGE}

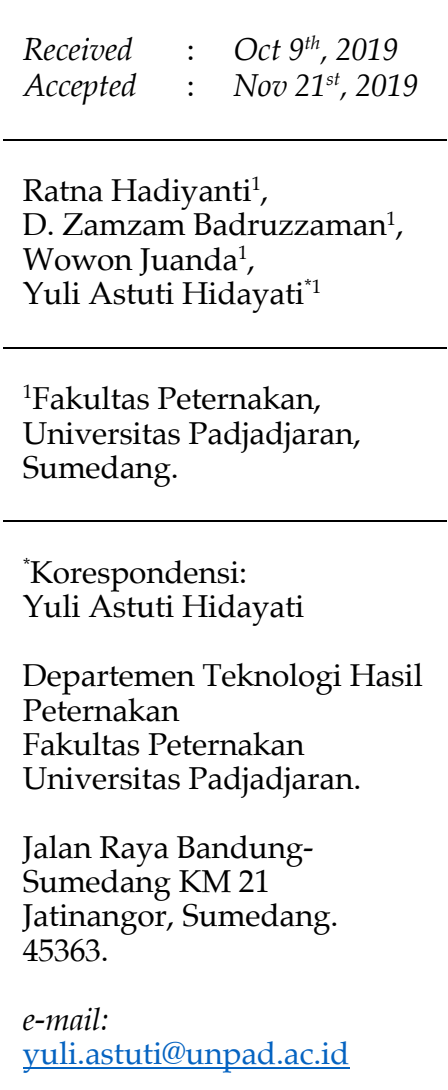

Abstract. Morinda citrifolia can be used as a natural disinfectant on the milk storage space because it has an antifungal compound. The purpose of this study is to determine the potential of Morinda citrifolia extract as a natural disinfectant to fungi in the milk storage room, is reviewed from a decrease in the number of mushrooms and identification of the type of fungi before and after the use of Morinda citrifolia extracts. The study was conducted experimentally using a complete random design (CRD) with four treatments of $\mathrm{P0}$ (without using Morinda citrifolia), P1 (15\% concentration of Morinda citrifolia extract), P2 (20\% concentration of Morinda citrifolia extract), P3 (concentration $25 \%$ of Morinda citrifolia extracts) and six times the replay. The observed is a decrease in the number of fungi, identifying the type of fungi before the use of Morinda citrifolia extract, identification of the type of fungi after the use of Morinda citrifolia extract. The results showed that Morinda citrifolia extract had a noticeable effect on decreasing the number of fungi in the milk storage room, with a consecutive drop percentage of $\mathrm{P} 0=25,12 \%$, P1 = $58,12 \%, \mathrm{P} 2=61,89 \%, \mathrm{P} 3=70,59 \%$. The result of identification of fungi type on milk storage Chamber is Cephalosporium sp, Aspergillus ochraceus, Aspergillus flavus, Penicillium purpurogenum, Penicillium digitatum, Mucor sp. The decrease in the amount of the type of each fungus is Cephalosporium sp (68,13\%), Aspergillus ochraceus (88\%), Aspergillus flavu $(87,94 \%)$, Penicillium purpurogenum $(85,71 \%)$, Penicillium digitatum (95.73\%), Mucor sp (59,57\%).

Keywords: Morinda citrifolia, disinfectant, fungi, milk storage room.

\section{PENDAHULUAN}

Ruang penyimpanan susu (lantai) merupakan tempat penampungan susu sebelum diolah dan didistribusikan. Kebersihan dari ruang penampungan susu akan mempengaruhi kualitas susu selanjutnya, sehingga sanitasi dari ruang penampungan susu perlu diperhatikan. Sumber kontaminan bisa berasal dari 
pekerja, peralatan, tempat penampungan, kontaminan yang sering ditemukan pada ruang penampungan susu berupa jamur dan bakteri. Susu segar biasanya mengandung $10^{3}-10^{5}$ CFU / mL jamur (Lavoie et al., 2012) dan menurut (Marín et al., 2015) jamur yang mengkontaminasi ruang penampungan susu adalah Geotrichum, Fusarium, Penicillium dan terdapat juga dalam susu segar.

Jamur-jamur tersebut dapat dihambat pertumbuhannya degan memberikan perlakuan desinfektan pada ruang penampungan susu. Desinfektan yang digunakan selama ini berupa bahan kimia sintetis, yang mempunyai kelebihan dapat mengurangi bakteri dengan cepat, tetapi meninggalkan residu dan sulit terurai, makadari itu perlu digantikan dengan desinfektan alami, yang dapat digunakan diantaranya ekstrak buah mengkudu. Senyawa aktif yang terkandung dalam buah mengkudu dan bersifat desinfektan adalah tannin, fenol, alkaloid, flavonoid, glikosida, steroid dan terpenoid. (Kakad et al., 2015).

Penurunan jumlah jamur dipengaruhi olek konsentrasi desinfektan yang digunakan, seperti pernyataan yang disampaikan oleh (Jainkittivong et al., 2009) bahwa pertumbuhan C. Albicans dapat dihambat dengan penggunaan konsentrasi $50 \mathrm{mg} / \mathrm{mL}$ ekstrak buah $M$. citrifolia dan menurut (Barani et al., 2014) pertumbuhan C. albicans dapat dihambat dengan penggunaan konsentrasi $1000 \mu \mathrm{g} / \mathrm{mL}$ ekstrak buah mengkudu. Hasil penelitian dari Srinivasahan \& Durairaj (2014) partumbuhan 5 jamur yaitu $A$. niger, $A$. fumigatus, Monoscus purpureus, C. albicans dan Monoscus rubber dapat dihambat dengan ekstrak hidroetanolik buah mengkudu sebanyak 100 $\mu g$. Sedangkan menurut Menurut (Kakad et al., 2015) juga membuktikan bahwa pertumbuhan $A$. niger, $C$. albicans, dan $D$. flavida dapat dihambat dengan penggunaan ekstrak metanol dari daun mengkudu. Sedangkan menurut (Ali et al., 2012) pertumbuhan jamur pathogen pada buah cabai merah dapat dihambat dengan penggunaan konsentrasi ekstrak buah mengkudu 20\%. Menurut (Silva et al., 2017) pertumbuhan jamur Aspergillus, Penicillium, Rhizopus, Fusarium, dan Exserohilum dalam biji jagung dapat dihambat dengan minyak atsiri dari buah mengkudu. Tujuan penelitin ini adalah untuk mengetahui potensi ekstrak buah mengkudu sebagai desinfektan alami terhadap jamur pada ruang penyimpanan susu, ditinjau dari penurunan jumlah jamur dan identifikasi jenis jamur sebelum dan sesudah penggunaan ekstrak buah mengkudu.

\section{MATERI DAN METODE}

Materi yang digunakan dalam penelitian ini adalah ekstrak buah mengkudu, etanol 96\%, Aquadest, Antibiotik (Clorampenicol $250 \mathrm{mg}$ ), media Potato Dextrose Agar, Spirtus. Metode yang digunakan dalam penelitian ini adalah eksperimental, menggunakan rancangan acak lengkap (RAL) dengan empat perlakuan yaitu P0 (tanpa menggunakan buah mengkudu), P1 (konsentrasi 15\% ekstrak buah mengkudu), P2 (kon-sentrasi 20\% ekstrak buah meng-kudu), P3 (konsentrasi 25\% ekstrak buah meng-kudu) dan enam kali ulangan. Peubah yang diamati adalah penu-runan jumlah jamur, identifikasi jenis jamur sebelum penggunaan ekstrak buah mengkudu, identifikasi jenis jamur sesudah penggunaan ekstrak buah mengkudu.

Penelitian ini menggunakan Metode RODAC (The Replicate Organism Direct Agar Contact Methode) merupakan salah satu metode menghitung jumlah mikroorganisme, terutama dari suatu permukaan (peralatan, lantai, meja) dalam rangka pemantauan mikrobiologis (micro-biological monitoring) di lingkungan industri pangan. 
Peman-tauan tersebut bertujuan untuk menilai kualitas sanitasi atau hygiene lingkungan industri (Lukman \& Purnaman, 2009).

Pembuatan Ekstraks Buah Mengkudu: menyiapkan simplisia buah mengkudu sebanyak $500 \mathrm{~g}$ dihaluskan menggunakan blender, kemudian melakukan maserasi dengan merendam serbuk simplisia buah mengkudu ke dalam pelarut etanol $96 \%$, perbandingan $1: 3$, sampai terendam seluruhnya selama \pm 24 jam, kemudian disaring. Kemudian residu simplisia buah mengkudu kembali dimaserasi lagi dengan cara yang sama dengan perbandingan perendaman 1:3, untuk dilakukan maserasi pada hari ke dua dan ke tiga. Selanjutnya hasil saringan (fitrat) yang dihasilkan kemudian diuapkan dengan menggunakan evaporator pada suhu $50^{\circ} \mathrm{C}$ sampai didapatkan ekstrak kental. (Pratiwa et al., 2015)

Aplikasi Ekstrak Buah Mengkudu sebagai Desinfektan: ekstrak buah mengkudu diencerkan sesuai perlakuan (P1 = konsentrasi 15\%, P2 = konsentrasi $20 \%, \mathrm{P} 3=$ konsentrasi 25\%), lalu disiapkan media Potato Dextrose Agar (PDA) ke dalam petridish setebal $5 \mathrm{~mm}$, kemudian ditempelkan pada lantai ruang penyimpanan susu, lalu diinkubasi selama 72 jam pada suhu $27^{\circ} \mathrm{C}$. Kemudian dilanjutkan dengan menyemprotkan desinfektan sesuai perlakuan pada lantai ruang penyimpanan susu dan dibiarkan selama 10 menit. Selanjutnya disiapkan lagi media PDA kedalam petridish setebal $5 \mathrm{~mm}$, lalu ditempelkan pada lantai ruang penyimpanan susu yang sudah disemprot dengan desinfektan sesuai perlakuan, lalu diinkubasi selama 72 jam pada suhu $27^{\circ} \mathrm{C}$. Lalu diamati jumlah koloni jamur yang tumbuh dan dinyatakan jumlah koloni per $100 \mathrm{~cm}^{2}$ dan dihitung menggunakan rumus:

$$
\left[\frac{\left[\frac{\sum \text { Mikroba }}{100 \mathrm{~cm} 2}\right]=\left[\frac{\bar{x} \text { koloni }}{\text { cawan }}\right] x}{100}\right]
$$

Perhitungan presentase penurunan jumlah jamur menggunakan rumus (Lukman \& Purnawarman, 2009):

$$
\frac{\sum \text { Jamur Awal- }-\sum \text { Jamur Akhir }}{\sum \text { Jamur Awal }} \times 100 \%
$$

Identifikasi jamur secara makroskopis dan mikroskopis: jamur yang tumbuh pada setiap perlakuan diamati dan diidentifikasi berdasarkan referensi, kemudian menyiapkan media PDA pada object glass, lalu menanam isolat jamur kontaminan yang akan diuji pada object glass dan ditutup dengan cover glass, kemudian diinkubasi selama 5 hari pada suhu $27^{\circ} \mathrm{C}$ dan selanjutnya diidentifikasi secara mikroskopis berdasarkan referensi. (Indrawati et al., 1999).

\section{HASIL DAN PEMBAHASAN}

a. Penurunan Jumlah Jamur pada Ruang Penyimpanan Susu.

Presentase penurunan jumlah jamur pada ruang penyimpanan susu disajikan pada gambar 1 . Berdasarkan hasil penelitian, pengaruh perlakuan P1 (konsentrasi 15\%) ekstrak buah mengkudu yang digunakan sebagai desinfektan alami pada ruang penyimpanan susu menghasilkan penurunan sebesar $58,21 \%$, perlakuan P2 (konsentrasi 20\%) menghasilkan penurunan sebesar 61,89\%, dan perlakuan P3 (konsentrasi 25\%) menghasilkan penurunan sebesar 70,59\%, sedangkan perlakuan P0 tanpa pemberian ekstrak buah mengkudu, menghasilkan penurunan sebesar $25,12 \%$, hal ini dikarenakan lantai pada ruang penyimpanan susu hanya dibersihkan menggunakan lap saja, sehingga penurunan jumlah jamurnya 
relatif rendah. Penurunan jumlah jamur ber-banding lurus dengan peningkatan konsentrasi penggunaan ekstrak buah mengkudu pada ruang penyimpanan susu. Hal ini sejalan dengan pendapat Jainkittivong et al., (2009) dan Barani et al., (2014) yang menyatakan ekstrak buah M. citrifolia dengan konsentrasi $50 \mathrm{mg} / \mathrm{mL}$ memiliki efek antijamur pada C. albicans dan ekstrak buah mengkudu dengan konsentrasi $1000 \mu \mathrm{\mu g} / \mathrm{mL}$ efektif menghambat pertumbuhan C. albicans. Sedangkan menurut Srinivasahan \& Durairaj (2014) mengatakan bahwa ekstrak hidroetanolik buah mengkudu sebanyak $100 \mu \mathrm{g}$ dapat menghambat pertumbuhan 5 jamur yaitu $A$. niger, $A$. fumigatus, Monoscus purpureus, $C$. albicans, dan Monoscus rubber dengan diameter zona hambat antara $9 \mathrm{~mm}$ sampai $12 \mathrm{~mm}$. Penurunan jumlah jamur yang diakibatkan penggunaan ekstrak buah mengkudu pada ruang penyimpanan susu, diakibatkan adanya senyawa aktif yang terkandung dalam buah mengkudu. Hal ini sejalan dengan pendapat Kakad et al., (2015) yang menyatakan bahwa buah mengkudu mengandung senyawa aktif tannin, fenol, alkaloid, flavonoid, glikosida, steroid, terpenoid dan bersifat desinfektan dan Kakad et al., (2015) juga membuktikan bahwa ekstrak metanol dari daun mengkudu dapat menghambat A. niger, $C$. albicans dan D. flavida dengan diameter zona hambat sebesar $22 \mathrm{~mm}$, $20 \mathrm{~mm}$ dan $17 \mathrm{~mm}$. Sedangkan menurut Silva et al., (2017) minyak atsiri dari buah mengkudu menghambat pertumbuhan jamur Aspergillus, Penicillium, Rhizopus, Fusarium, dan Exserohilum dalam biji jagung.

b. Identifikasi Jenis Jamur pada Ruang Penyimpanan Susu.

Hasil Identifikasi jenis jamur pada ruang penyimpanan susu sebelum dan sesudah penggunaan desinfektan ekstrak buah mengkudu disajikan pada Tabel 1 .

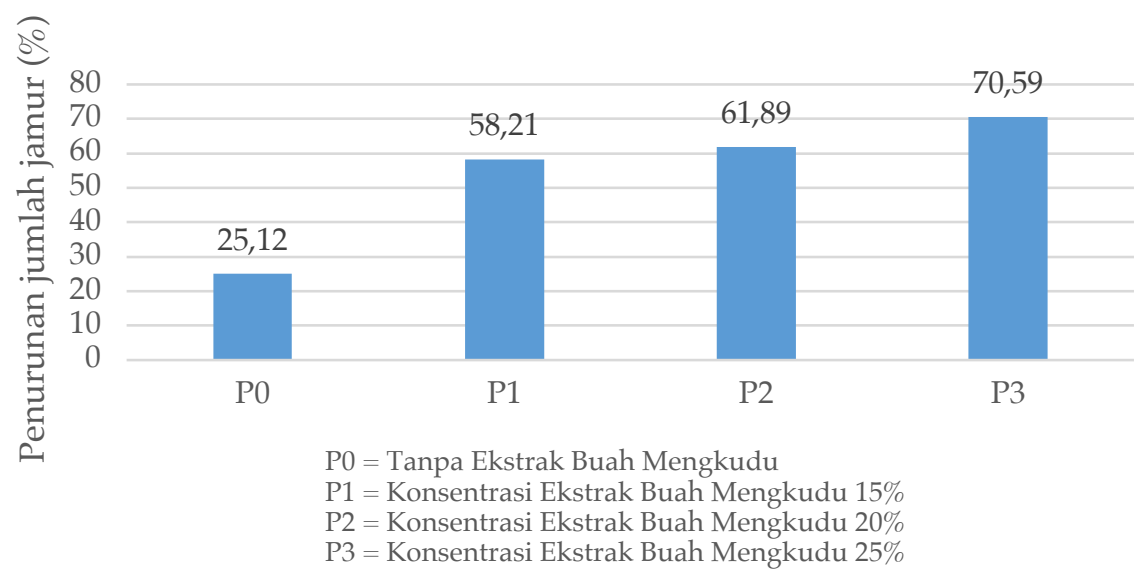

Gambar 1. Penurunan Jumlah Jamur pada Ruang Penyimpanan Susu 
Tabel 1. Identifikasi jenis jamur pada ruang penyimpanan susu sebelum dan sesudah penggunaan desinfektan ekstrak buah mengkudu

\begin{tabular}{ccc}
\hline No & $\begin{array}{c}\text { Jenis Jamur sebelum penggunaan } \\
\text { desinfektan ekstrak buah mengkudu }\end{array}$ & $\begin{array}{c}\text { Jenis Jamur sesudah penggunaan } \\
\text { desinfektan ekstrak buah mengkudu }\end{array}$ \\
\hline 1 & Cephalosporium sp. & Cephalosporium sp. \\
2 & Aspergillus ocehraceus & Aspergillus ocehraceus \\
3 & Aspergillus flavus & Aspergillus flavus \\
4 & Penicillium purpurogenum & Penicillium purpurogenum \\
5 & Penicillium digitatum & Penicillium digitatum \\
6 & Mucor sp. & Mucor sp. \\
\hline
\end{tabular}

Hasil penelitian menunjukkan bahwa jamur-jamur yang teridentifikasi sebelum penggunaan ekstra buah mengkudu pada ruang penyimpanan susu adalah Cepha-losporium sp., Aspergillus ocehraceus, Aspergillus flavus, Penicillium purpurogenum, Penicillium digitatum, dan Mucor sp. merupakan jamur-jamur yang berasal dari lingkungan dan mengkontaminasi ruang penyimpanan susu. Hal ini sejalan dengan hasil penelitian Nunik \& Supratini (2005) yang mengidentifikasi jamur dari lingkungan (pakan, tempat pemerahan, tanah dan sumber air) ditemukan antara lain Aspergillus sp, Penicillium sp, Geotricum sp, dan Rizophus sp.

Jenis jamur yang teridentifikasi setelah penggunaan ekstrak buah mengkudu pada ruang penyimpanan susu masih sama dengan awal pemeriksaan sebelum penggunaan ekstrak buah mengkudu pada ruang penyimpanan susu, namun demikian jumlahnya berkurang. Sedangkan menurut Marín et al., (2015) jamur yang dapat diisolasi dari susu segar adalah Geotrichum, Fusarium, Penicillium dan dapat mengkontaminasi ruang penampungan susu. Jamur-jamur yang ber-hasil teridentifikasi pada ruang penyimpanan susu adalah Cephalosporium sp., Aspergillus ocehraceus, Aspergillus flavus, Penicillium purpu-rogenum, Penicillium digitatum, dan Mucor sp. Jamur-jamur tersebut merupakan jamur yang bersifat patogen baik pada manusia, hewan maupun tum-buhan, dan susu sangat mudah terkontaminasi, sehingga jamur-jamur tersebut diharapkan tidak tumbuh pada ruang penampungan susu.

c. Pengaruh Ekstrak Buah Mengkudu Terhadap Penurunan Jumlah Masing-masing jenis Jamur yang teridentifikasi pada Ruang Penyimpanan Susu.

Hasil isolasi penurunan jumlah masing-masing jamur yang teridentifikasi pada ruang penyimpanan susu disajikan pada Gambar 2. 


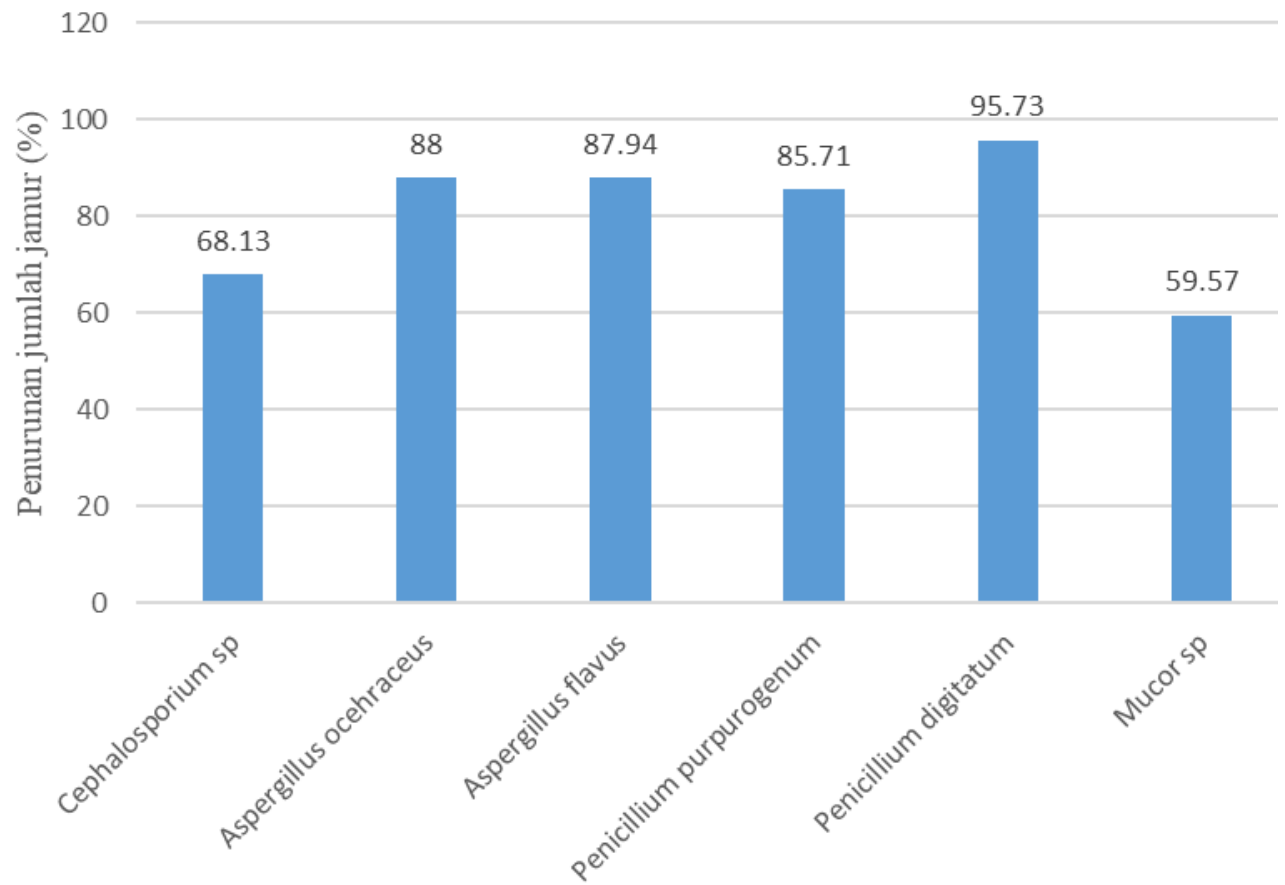

Gambar 2. Penurunan Jumlah Masing -masing Jamur yang Teridentifikasi pada Ruang Penyimpanan Susu

Berdasarkan hasil penelitian menunjukkan bahwa semua jenis jamur yang teridentifikasi menghasilkan presentase penurunan ber-kisar $59.57-88 \%$, hal ini menggambarkan bahwa senyawa aktif yang terkandung dalam ekstrak buah mengkudu efektif menghambat per-tumbuhan jamur. Hal ini sejalan dengan pendapat (Jayaraman et al., 2008) yang menyatakan ekstrak daun mengkudu juga dapat menghambat pertumbuhan jamur Penicillium, Fusarium, Rhizopus, dan Mucor mendekati 50\%.

\section{KESIMPULAN}

1. Konsentrasi ekstrak buah mengkudu (15-25\%) menurunkan jumlah jamur pada ruang penyimpanan susu.

2. Hasil Identifikasi jenis jamur pada ruang penyimpanan susu adalah Cephalosporium sp., Aspergillus ochra-ceus, Aspergillus flavus, Penicillium purpurogenum, Penicillium digitatum, dan Mucor sp.
3. Senyawa aktif yang terkandung dalam ekstrak buah mengkudu efektif menghambat partumbuhan jamur berkisar 59.57-88\%.

\section{DAFTAR PUSTAKA}

Ali, M., Fifi, P., Molehet, M., \& Siburian. (2012). Uji Beberapa Konsentrasi Ekstrak Buah Mengkudu (Morinda citrifolia L.) Terhadap Penyakit Antraknosa Yang Disebabkan Oleh Jamur Colletotrichum capsici Pada Buah Cabai Merah Pascapanen. Agricultural Science and Technology Journal, 11(2):1-16. ISSN 1412-4424.

Barani, K., Manipal, S., Prabu, D., Ahmed, A., Adusumilli, P., \& Jeevika, C. (2014). Anti-Fungal Activities of Morinda citrifolia (Noni) Extracts Against Candida albicans: An in Vitro Study. Indian Journal Dent Res, 25(2):188-90. 
Denny, W., Lukman, \& Trioso, P., (2009). Analisis Penuntun Praktikum Higiene Pangan Asal Hewan, Bagian Kesehatan Masyarakat Veteriner Departemen Ilmu Penyakit Hewan dan Kesmavet Fakultas Kedokteran Hewan IPB. Bogor. 10, 43, 46.

Jainkittivong, A., Butsarakamruha, T., Langlais R.P. (2009). Antifungal activity of Morinda citrifolia fruit extract against Candida albicans. Oral Surgery, Oral Medicine, Oral Pathology, Oral Radiology, and Endodontology, 108(3):394-398.

Jayaraman S. K., Manoharan M. S., \& Illanchezian, S. (2008). Antibacterial, antifungal, and tumor cell suppression potensial of Morinda citrifolia fruit extracts. International Journal of Integrative Biology (IJIB), 3(1):44-49.

Kakad, S. L., Pise, S. S., \& Dhembares, A. J. (2015). Evaluation of Phytochemical, Antibacterial, Antifungal Activities of Leaf Extracts of Morinda citrifolia (Linn). Der Pharmacia Sinica, 6(4):19-12.

Indrawati, G., Rober, A. S., Karin, A., \& Iman Santoso. (1999). Pengenalan Kapang Tropik Umum. Edisi Pertama. Diterbitkan oleh Yayasan Obor Indonesia. Kerjasama Universitas Indonesia dengan Centralbureau voor Schimmelcultures Baarn. The Netherlands.

Lavoie, K., Marilyne Touchette, Daniel St-Gelais, \& Steve Labrie. (2012). Characterization of the fungal microflora in raw milk and specialty cheeses of the province of
Quebec. Dairy Science and Technology, 92(5):455-468.

Marín, P., Daniel Palmero, \& Miguel Jurado. (2015). Occurrence of moulds associated with ovine raw milk and cheeses of the Spanish region of Castilla La Mancha. International Journal of Dairy Tecnology, 68(4):565-572.

Nunik, A. S., \& Supratini. (2005). Pengamatan Jenis-jenis Jamur yang ditemukan pada Minuman Susu Segar dan Susu Kemasan. Media Litbang Kesehatan. Volume XV No.3.

Pratiwa, Chandra, Dipa, Farah, \& Wahdina. (2015). Bioaktivitas Ekstrak Etanol Buah Mengkudu (Morinda citrifolia L.) terhadap rayap tanah (Cooptotermes curviganathus Holmgren). Universitas Tanjungpura, Pontianak. 3(2): 227-233.

Silva, J. C. E., Dalmarcia de Sousa Carlos Mourão, Fabia Silva de Oliveira Lima, Renato de Almeida Sarmento, Mateus Sunti Dalcin, Raimundo Wagner de Souza Aguiar, \& Gil Rodrigues dos Santos. (2017). The Efficiency of Noni (Morinda citrifolia L.) Essential Oil on the Control of Leaf Spot Caused by Exserohilum turcicum in Maize Culture. Medicines, 4(3):60. doi:10.3390/ medicines 4030060 .

Srinivasahan, V. \& Durairaj, B. (2014). Antimicrobial activities of hydroethanolic extract of Morinda citrifolia fruit. International Journal of Current Microbiology and Applied Sciences, 3(9):26-33. 